\title{
Preparation of a Counter Electrode with P-Type NiO and Its Applications in Dye-Sensitized Solar Cell
}

\author{
Chuen-Shii Chou, ${ }^{1,2}$ Chin-Min Hsiung, ${ }^{1,2}$ Chun-Po Wang, ${ }^{2}$ \\ Ru-Yuan Yang, ${ }^{1,3}$ and Ming-Geng Guo ${ }^{2}$ \\ ${ }^{1}$ Research Center of Solar Photo-Electricity Applications, National Pingtung University of Science and Technology, \\ Pingtung 912, Taiwan \\ ${ }^{2}$ Powder Technology ReD Laboratory, Department of Mechanical Engineering, \\ National Pingtung University of Science and Technology, Pingtung 912, Taiwan \\ ${ }^{3}$ Department of Materials Engineering, National Pingtung University of Science and Technology, Pingtung 912, Taiwan
}

Correspondence should be addressed to Chuen-Shii Chou, cschou@mail.npust.edu.tw

Received 30 November 2009; Revised 20 March 2010; Accepted 10 May 2010

Academic Editor: Stephen M. Goodnick

Copyright $(\odot) 2010$ Chuen-Shii Chou et al. This is an open access article distributed under the Creative Commons Attribution License, which permits unrestricted use, distribution, and reproduction in any medium, provided the original work is properly cited.

\begin{abstract}
This study investigates the applicability of a counter electrode with a $P$-type semiconductor oxide (such as NiO) on a dye-sensitized solar cell (DSSC). The counter electrode is fabricated by depositing an NiO film on top of a Pt film, which has been deposited on a Fluorine-doped tin oxide (FTO) glass using an ion-sputtering coater (or E-beam evaporator), using a simple spin coating method. This study also examines the effect of the average thickness of $\mathrm{TiO}_{2}$ film deposited on a working electrode upon the power conversion efficiency of a DSSC. This study shows that the power conversion efficiency of a DSSC with a Pt(E)/ $\mathrm{NiO}$ counter electrode (4.28\%) substantially exceeds that of a conventional DSSC with a $\mathrm{Pt}(\mathrm{E})$ counter electrode (3.16\%) on which a Pt film was deposited using an E-beam evaporator. This result is attributed to the fact that the NiO film coated on the Pt(E) counter electrode improves the electrocatalytic activity of the counter electrode.
\end{abstract}

\section{Introduction}

Solar power is the most notable among renewable energy resources because of its low environmental impact and global availability. Among alternative forms of solar cells, dyesensitized solar cells (DSSCs), as proposed by O'Regan and Grätzel [1], have attracted considerable interest since 1991 because of its properties, such as low production cost and low environmental impact during fabrication $[2,3]$.

In the past few years (2006-2009), several methods have been utilized in modifying the structure of a working electrode $\left(\mathrm{TiO}_{2}\right.$ electrode $)$ to improve the performance of DSSCs [4-22]. Novel sensitizers were synthesized and applied in DSSCs to promote the absorption of the visible spectrum [3, 23-29]. Novel electrolytes were proposed to prevent leakage of the electrolyte or to increase the lifetime (or performance) of DSSCs [30-35]. Moreover, a quasisolid DSSC with straight ion paths based on an anodically oxidized
$\mathrm{Al}_{2} \mathrm{O}_{3}$ film, which was full of nanopores from one side of the film to the other, was presented [36].

The counter electrode is an equally important component of the DSSC. The role of the counter electrode is to transfer electrons from an external circuit to the tri-iodide and iodine in the redox electrolyte. Currently, a layer of platinum $(\mathrm{Pt})$ coated on a transparent conducting oxide (TCO) substrate is widely used as a counter electrode in DSSCs. Besides platinum $(\mathrm{Pt})$, carbon materials (such as graphite powder and carbon black [37, 38], hard carbon spherule [39], single-walled carbon nanotubes [40], multiwalled carbon nanotubes [41], and nanosized carbon powder [42, 43]) have been used to prepare platinum-free counter electrodes.

Aside from the carbon materials, counter electrodes with metal oxide biphase materials (such as $\mathrm{Pt} / \mathrm{NiO}$ [44, 45] and $\mathrm{Pt} / \mathrm{TiO}_{2}$ [45]) have been prepared using an $\mathrm{RF}$ magnetron cosputtering system. However, these highly efficient $\mathrm{Pt} / \mathrm{NiO}$ (or $\mathrm{Pt} / \mathrm{TiO}_{2}$ ) bi-phase counter electrodes are 


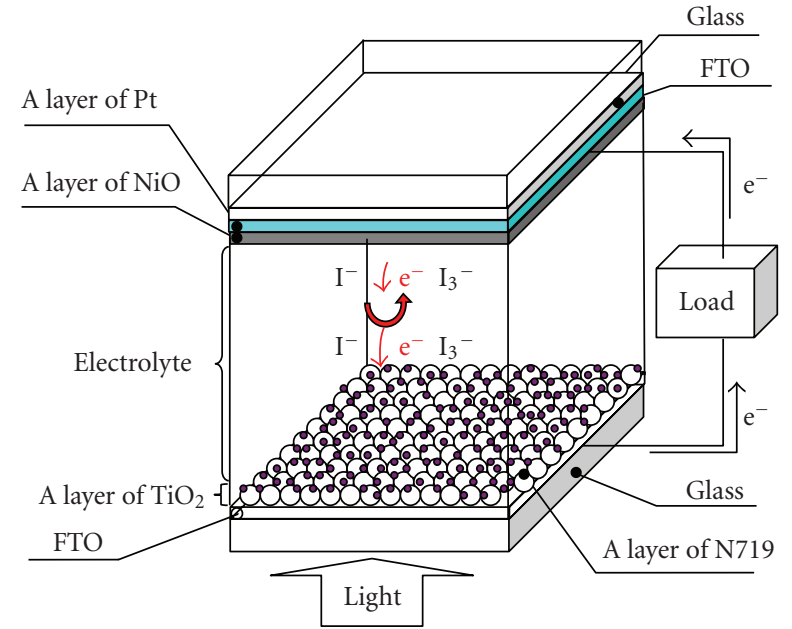

FIGURE 1: Schematic of the dye-sensitized solar cell with a $\mathrm{Pt} / \mathrm{NiO}$ counter electrode.

obtained using an expensive vacuum technology which requires a sophisticated process control. Aside from this observation, Kay and Grätzel reported that a small amount of platinum might be dissolved in the electrolyte by oxidation and complex formation with iodide/tri-iodide (such as $\mathrm{PtI}_{4}$ or $\mathrm{H}_{2} \mathrm{PtI}_{6}$ ) [37]. This may degrade the performance of counter electrodes after a certain period of exposure to light. Accordingly, decreasing the oxidation of Pt film in contact with the electrolyte is one of the most important factors in increasing the power conversion efficiency of DSSC; this is worthy of further study.

Therefore, in this study, a simple method (i.e., spin coating) was used to deposit a $\mathrm{NiO}$ film on top of a $\mathrm{Pt}$ film (Figure 1), which had been deposited on a FTO-glass (Fluorine-doped tin oxide, $\mathrm{SnO}_{2}: \mathrm{F}$ ) substrate using an Ebeam evaporator (or ion-sputter coater) to protect the $\mathrm{Pt}$ film from oxidation and corrosion. The effect of $P$-type $\mathrm{NiO}$ on the electrocatalytic activity of the counter electrode and the power conversion efficiency of DSSC was investigated. A comparison of a DSSC with the proposed counter electrode with the conventional DSSC was also made in this study.

\section{Experimental Details}

The experiments involved (1) preparing the colloid of $\mathrm{TiO}_{2}$ particles (P-25); (2) preparing the working electrode and measuring its properties; (3) preparing the colloid of $P$-type $\mathrm{NiO}$; (4) preparing the counter electrode and measuring its properties; (4) assembling the DSSC by fitting the working electrode, the counter electrode, the electrolyte, and the copper conductive tape; (5) making J-V measurements of the DSSC.

2.1. Preparing and Measuring the Working Electrode. Fabricating a DSSC working electrode with a film of $\mathrm{TiO}_{2}$ particles (Figure 1) followed these steps: (1) a colloid of $\mathrm{TiO}_{2}$ particles (P-25) was prepared and homogenized; (2) using spin coating, the colloid of $\mathrm{TiO}_{2}$ particles was deposited on top of a FTO-glass substrate, and it was then sintered at $500^{\circ} \mathrm{C}$ for $1 \mathrm{~h}$ in a high-temperature furnace (Thermolyne, 46100); (3) the FTO-glass substrate with the film of $\mathrm{TiO}_{2}$ particles was immersed into a $\left(3 \times 10^{-4} \mathrm{M}\right)$ solution of N-719 dye (Ruthenium, $\mathrm{RuL}_{2}(\mathrm{NCS})_{2}$ ) and ethyl alcohol $\left(\mathrm{CH}_{3} \mathrm{CH}_{2} \mathrm{OH}\right.$, $95 \%)$ at $70^{\circ} \mathrm{C}$ for $6 \mathrm{~h}$. The area of $\mathrm{TiO}_{2}$ electrode of DSSC was $0.25 \mathrm{~cm}^{2}$ in this study.

An $\alpha$-step (Dekeak 6M) surface profiler was utilized to obtain the average thickness of the film on the FTO-glass substrate of the working electrode. In order to show the crystal structure of the $\mathrm{TiO}_{2}$ powder, which was obtained by heating the solution of $\mathrm{TiCl}_{4}$, its X-ray diffraction (XRD) patterns were measured using a powder X-ray diffractometer (Shimadzu, XRD-6000).

2.2. Preparing and Measuring the Counter Electrode. The procedure for fabricating a counter electrode of DSSC with a film of Pt sandwiched between a NiO film and a FTO-glass substrate (Figure 1) is as follows. (1) The P-type $\mathrm{NiO}$ was obtained by annealing the Ni powder in a high-temperature furnace at $500^{\circ} \mathrm{C}$; (2) the $\mathrm{NiO}$ colloid was prepared by mixing $1 \mathrm{~g}$ of $\mathrm{NiO}$ with solvents $(20 \mathrm{ml}$ of DI water, $1 \mathrm{ml}$ of ethanol, $0.1 \mathrm{ml}$ of acetylacetone, and $0.1 \mathrm{ml}$ of Triton X-100) and then homogenized in an ultrasonic homogenizer for $30 \mathrm{~min}$; (3) using spin coating, 2-3 $\mathrm{ml}$ of the $\mathrm{NiO}$ colloid was deposited on top of a Pt film, which had been deposited on the FTOglass substrate using an E-beam evaporator (or ion-sputter coater); (4) this substrate was then sintered at $500^{\circ} \mathrm{C}$ for $1 \mathrm{~h}$ in a high-temperature furnace.

In this study, in order to show the effect of the vacuum level on the performance of a DSSC, an E-beam evaporator (Kaoduen Tech. Corp.) with a vacuum level of $4 \times 10^{-7}$ Torr and an ion-sputter coater (Hitachi E-1010) with a vacuum level of $10^{-2}$ Torr were used to deposit a Pt film on the FTOglass substrate of the counter electrode. The area of a Pt film of counter electrode was $4.0 \mathrm{~cm}^{2}$ in this study. Aside from this, the two-stage spin coating was used in this study: (1) in the first stage, the rotation speed of $1000 \mathrm{rpm}$ and the duration of $5 \mathrm{~s}$ were used to remove the extra $\mathrm{NiO}$ colloid from the substrate; (2) in the second stage, the rotation speed of $1500 \mathrm{rpm}$ and the duration of $15 \mathrm{~s}$ were used to homogenize the $\mathrm{NiO}$ film on the substrate.

The image and the micrograph of the counter electrode with a Pt film were obtained using a digital camera (Panasonic DMC-LZ2) and a scanning electron microscope (HITACHI S-4700), respectively. The reflectance and the cyclic voltammogram $(\mathrm{CV})$ of the counter electrode were obtained using a UV-VIS-NIR spectrophotometer (Jasco V$600)$ and an electrochemical workstation (CH Instruments CHI-660C), respectively. Further, the surface roughness and the 3D micrograph of the counter electrode were obtained using a atomic force microscope (Digital Instrument NanoMan-NS4+D3100).

2.3. Assembling and Testing the DSSC. The working electrode, the counter electrode, and the copper conductive tape (Ted Pella) were fitted together, with the space between two electrodes adjusted to approximately $25 \mu \mathrm{m}$ for the liquid 


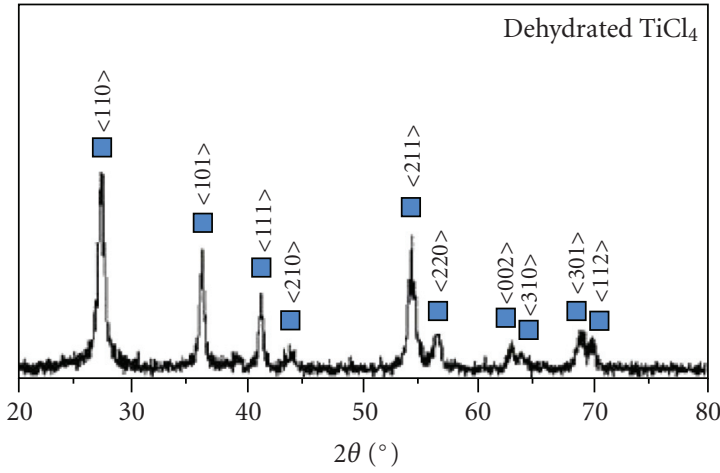

Rutile

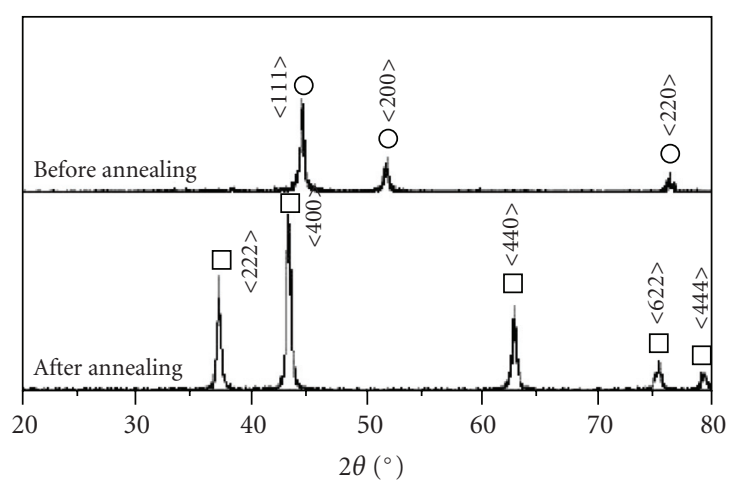

$\bigcirc \mathrm{Ni}$

$\square \mathrm{NiO}$

(a)

(b)

Figure 2: XRD patterns of $\mathrm{Ni}, \mathrm{NiO}$, and dehydrated $\mathrm{TiCl}_{4}$.

electrolyte. After sealing, the liquid electrolyte was injected into the cell through a prepared hole in the cell. The detailed preparation of the photoanode and the DSSC assembly were presented in [22].

A digital source meter (Keithley 2000) measured the open-circuit photovoltage and the short-circuit photocurrent of the DSSC, and a solar simulator (Science Tech. SS150) illuminated the DSSC. The power conversion efficiency $\eta$ of the DSSC is determined by

$$
\eta(\%)=\frac{V_{\mathrm{oc}} J_{\mathrm{sc}} F F}{P_{\mathrm{in}}} \times 100,
$$

where $V_{o c}, J_{s c}$, and $P_{\text {in }}$ represent the open-circuit photovoltage, the short-circuit photocurrent per unit area, and the incident light power $\left(100 \mathrm{~mW} / \mathrm{cm}^{2}\right)$, respectively. Aside from this, fill factor (FF) is given by

$$
F F=\frac{V_{\max } J_{\max }}{V_{\mathrm{oc}} J_{\mathrm{sc}}},
$$

where $V_{\max }$ and $J_{\max }$ represent the voltage and the current per unit area at the maximum output power point, respectively.

\section{Results and Discussion}

3.1. Characteristics of $\mathrm{TiCl}_{4}$ and $\mathrm{NiO}$. Figure 2 shows the Xray diffraction (XRD) patterns of dehydrated $\mathrm{TiCl}_{4}$, as well as powders of $\mathrm{Ni}$ and $\mathrm{NiO}$. The solid square, circle, and square in Figure 3 represent rutile, $\mathrm{Ni}$, and $\mathrm{NiO}$, respectively. From JCPDS 89-4920 (rutile), the XRD patterns of the dehydrated $\mathrm{TiCl}_{4}$ show that three major peaks of rutile at $2 \theta=27.47^{\circ}, 2 \theta=36.14^{\circ}$, and $2 \theta=54.31^{\circ}$ correspond to the diffraction from the $\langle 110\rangle,\langle 101\rangle$, and $<211\rangle$ planes, respectively. The purpose of immersing a FTO-glass substrate in the $\mathrm{TiCl}_{4}$ solution before depositing the $\mathrm{TiO}_{2}(\mathrm{P}-25)$ colloid is to prevent the FTO-glass substrate from dye (or electrolyte) contamination, which might penetrate through the cavities of the $\mathrm{TiO}_{2}$ (P-25) film. Ito et al. observed that $\mathrm{TiCl}_{4}$ treatment induced improvements in the adhesion and mechanical strength of a nanocrystalline $\mathrm{TiO}_{2}$ layer [22] .
From JCPDS 89-5881 (nickel oxide), the XRD patterns of the $\mathrm{NiO}$ powder, obtained by annealing the Ni powder, show that three major peaks of $\mathrm{NiO}$ at $2 \theta=37.3^{\circ}, 2 \theta=43.3^{\circ}$, and $2 \theta=62.9^{\circ}$ correspond to the diffraction from the $<222>$, $<400>$, and $<440>$ planes, respectively. Instead of depositing and annealing $\mathrm{Ni}$ to form a $\mathrm{NiO}$ deposit on platinum, we have preferred to spin coat a previously formed $\mathrm{NiO}$ before sintering. This is because, compared with the $\mathrm{Ni}$ powder, $\mathrm{NiO}$ powder can be more easily dispersed in the solvent.

3.2. Characteristics of the Counter Electrode. This study used four kinds of counter electrode: (1) a counter electrode with a Pt film deposited on the FTO-glass substrate using an Ebeam evaporator (called $\mathrm{Pt}(\mathrm{E}))$, (2) a counter electrode with a Pt film deposited on the FTO-glass substrate using an ionsputter coater (called $\mathrm{Pt}(\mathrm{S})$ ), (3) a counter electrode prepared by depositing a $\mathrm{NiO}$ film on top of $\mathrm{Pt}(\mathrm{E})$ (called $\mathrm{Pt}(\mathrm{E}) / \mathrm{NiO}$ ), and (4) a counter electrode prepared by depositing a $\mathrm{NiO}$ film on top of $\mathrm{Pt}(\mathrm{S})$ (called $\mathrm{Pt}(\mathrm{S}) / \mathrm{NiO}$ ).

Figure 3 shows the images and the SEM micrographs $(20 \mathrm{kx})$ of the counter electrodes of $\mathrm{Pt}(\mathrm{E})$ and $\mathrm{Pt}(\mathrm{S})$. Figure 4 shows the variations in reflectance with light wavelength of the $\mathrm{Pt}(\mathrm{E}), \mathrm{Pt}(\mathrm{S}), \mathrm{t}(\mathrm{E}) / \mathrm{NiO}$, and $\mathrm{Pt}(\mathrm{S}) / \mathrm{NiO}$ counter electrodes. For the counter electrodes used in this study, the reflectance increases with an increase in wavelength. For example, for the $\mathrm{Pt}(\mathrm{E})$ counter electrode, as the wavelength increases to $800 \mathrm{~nm}$, its reflectance goes up to $50.4 \%$ (Figure 4 ). The light-reflecting character of the Pt film is desirable because it increases the light harvesting efficiency of the sensitizing dye $[45,46]$. Aside from this, at a fixed wavelength, the reflectance of the $\mathrm{Pt}(\mathrm{E})$ counter electrode substantially exceeds that of the $\mathrm{Pt}(\mathrm{S})$ counter electrode. For example, at a fixed wavelength of $800 \mathrm{~nm}$, the reflectance of the counter electrodes of $\mathrm{Pt}(\mathrm{E})$ and $\mathrm{Pt}(\mathrm{S})$ are $50.4 \%$ and $13.4 \%$, respectively. This result is attributed to the fact that the vacuum level of the ion-sputter coater used in this study $\left(10^{-2}\right.$ Torr) is not higher than that of the E-beam evaporator $\left(4 \times 10^{-7}\right.$ Torr), so the target (such as $\mathrm{Pt}$ ) and the residual 


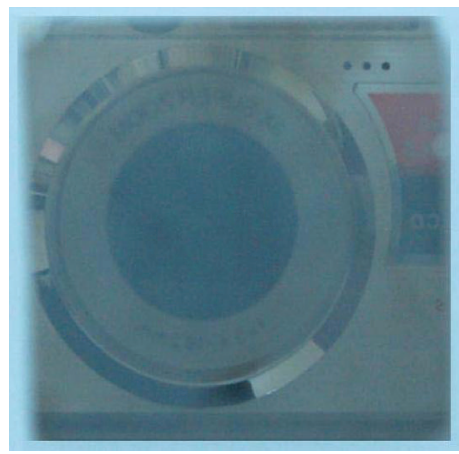

(a)

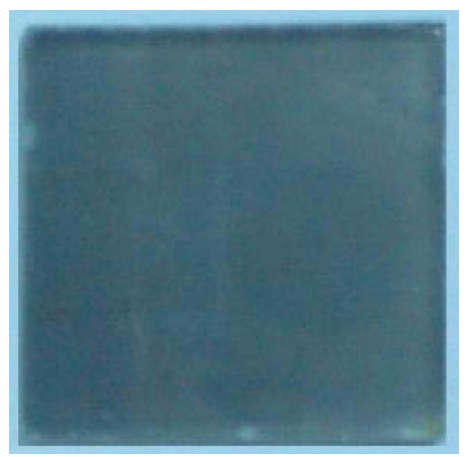

(c)

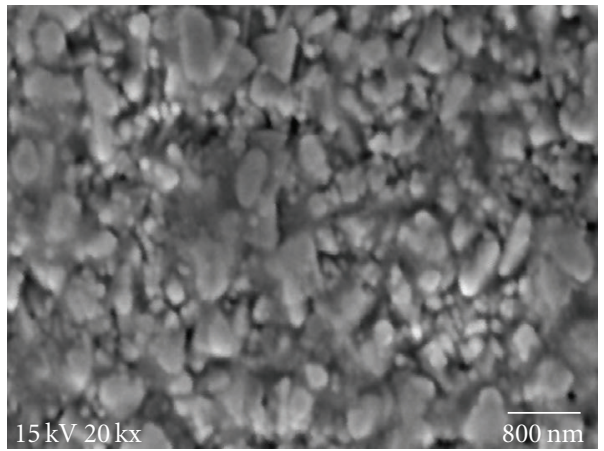

(b)

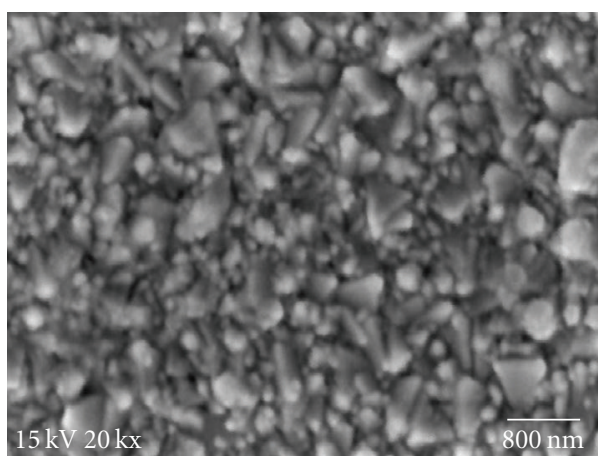

(d)

Figure 3: Image of the $\mathrm{Pt}(\mathrm{E})$ counter electrode (a), SEM micrograph (20 kx) of the $\mathrm{Pt}(\mathrm{E})$ counter electrode (b), image of the Pt(S) counter electrode (c), and SEM micrograph $(20 \mathrm{kx})$ of the $\mathrm{Pt}(\mathrm{S})$ counter electrode $(\mathrm{d})$.

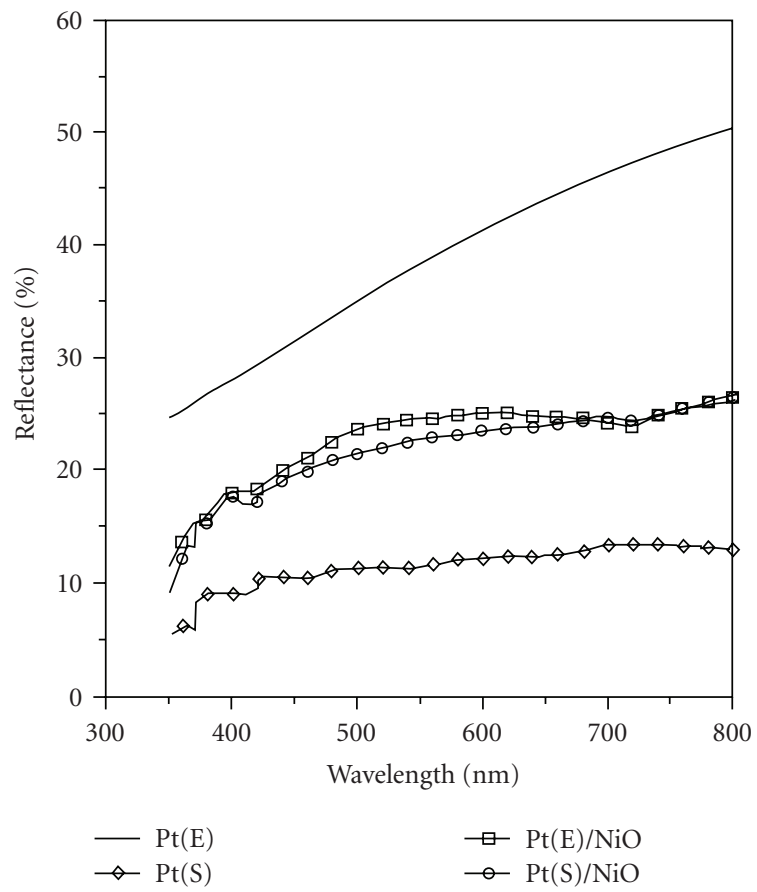

FIgure 4: Variations in reflectance with the wavelength of the light for counter electrodes of $\mathrm{Pt}(\mathrm{E}), \mathrm{Pt}(\mathrm{S}), \mathrm{Pt}(\mathrm{E}) / \mathrm{NiO}$, and $\mathrm{Pt}(\mathrm{S}) / \mathrm{NiO}$. 
TABLE 1: Test conditions and power conversion efficiencies of DSSCs.

\begin{tabular}{|c|c|c|c|c|c|c|c|c|}
\hline \multicolumn{4}{|c|}{ Counter Electrode } & Working Elect rode & $J_{S C}\left(\mathrm{~mA} / \mathrm{cm}^{2}\right)$ & $V_{\mathrm{OC}}$ & $\mathrm{FF}(\%)$ & $\eta(\%)$ \\
\hline & & RMS(nm) & $\mathrm{Ra}(\mathrm{nm})$ & Average film thickness $(\mu \mathrm{m})$ & & & & \\
\hline D1 & $\operatorname{Pt}(\mathrm{E})$ & 18.570 & 14.213 & 12.0 & 9.15 & 0.65 & 50.42 & 3.00 \\
\hline D2 & & & & 19.0 & 9.27 & 0.65 & 52.49 & 3.16 \\
\hline D3 & $\operatorname{Pt}(\mathrm{S})$ & 16.734 & 12.894 & 11.0 & 6.11 & 0.65 & 58.64 & 2.33 \\
\hline D4 & & & & 15.0 & 8.28 & 0.65 & 44.98 & 2.34 \\
\hline D5 & $\mathrm{Pt}(\mathrm{E}) / \mathrm{NiO}$ & 123.30 & 97.321 & 12.4 & 9.05 & 0.65 & 59.77 & 3.51 \\
\hline D6 & & & & 16.0 & 10.44 & 0.65 & 63.15 & 4.28 \\
\hline D7 & $\mathrm{Pt}(\mathrm{S}) / \mathrm{NiO}$ & 112.46 & 92.859 & 13.1 & 7.70 & 0.65 & 56.40 & 2.82 \\
\hline D8 & & & & 14.8 & 8.45 & 0.65 & 50.06 & 2.92 \\
\hline
\end{tabular}

Note: “(E)”, “(S)”, RMS, and Ra represent E-beam evaporator, sputtering, root mean square, and roughness average.

substance in the chamber are probably deposited on the substrate during sputtering. Therefore, unlike the $\mathrm{Pt}(\mathrm{E})$ counter electrode, the $\mathrm{Pt}(\mathrm{S})$ counter electrode is not able to mirror the digital camera, which was used to take images of the counter electrodes (Figure 3). At $800 \mathrm{~nm}$ wavelength, the reflectance of the $\mathrm{Pt}(\mathrm{E}) / \mathrm{NiO}$ counter electrode $(26.6 \%)$ is close to that of the $\mathrm{Pt}(\mathrm{S}) / \mathrm{NiO}$ counter electrode $(26.2 \%)$. Further, the sheet resistance of the $\mathrm{Pt}(\mathrm{S})$ counter electrode $(9.73 \Omega / \mathrm{sq})$ also substantially exceeds that of the $\mathrm{Pt}(\mathrm{E})$ counter electrode $(5.57 \Omega / \mathrm{sq})$.

Figure 5 shows the 3-D microstructures of the $\mathrm{Pt}(\mathrm{E})$, $\mathrm{Pt}(\mathrm{S}), \mathrm{Pt}(\mathrm{E}) / \mathrm{NiO}$, and $\mathrm{Pt}(\mathrm{S}) / \mathrm{NiO}$ counter electrodes. The surface roughness average $(\mathrm{Ra})$ of the $\mathrm{Pt}(\mathrm{E})$ counter electrode $(14.213 \mathrm{~nm})$ exceeds that of the $\operatorname{Pt}(\mathrm{S})$ counter electrode $(12.894 \mathrm{~nm})$, as shown in Figure 5. This is attributed to the fact that compared with evaporation, it is easier to maintain a stable deposition rate during sputtering, and it is also much easier to deposit a uniform film on a large area substrate [47]. Song and Lin observed that the hillock formation in a Pt/Ti film was obtained using UHV electron beam evaporation, but a rosette-type microstructure in the $\mathrm{Pt} / \mathrm{Ti}$ film was obtained using DC-sputtering [48]. Aside from this, Zhou et al. indicated that the increased roughness improved the light scattering of the counter electrode [49].

Figure 6 shows the CVs of the $\mathrm{Pt}(\mathrm{E}), \mathrm{Pt}(\mathrm{S}), \mathrm{Pt}(\mathrm{E}) / \mathrm{NiO}$, and $\mathrm{Pt}(\mathrm{S}) / \mathrm{NiO}$ counter electrodes. The oxidation and reduction peaks of $\mathrm{I}^{-} / \mathrm{I}_{3}^{-}$on these counter electrodes are similar. For example, their oxidation potential ranges from $0.4 \mathrm{~V}$ to $0.9 \mathrm{~V}$, and the reduction potential ranges from $0.0 \mathrm{~V}$ to $0.5 \mathrm{~V}$ (Figure 6). The presence of a $\mathrm{NiO}$ film enhances the current density during the redox process. For example, in the oxidation process, the highest current density of $\mathrm{Pt}(\mathrm{E}) / \mathrm{NiO}$ $\left(7.2 \mathrm{~mA} / \mathrm{cm}^{2}\right)$ exceeds that of $\mathrm{Pt}(\mathrm{E})\left(6.1 \mathrm{~mA} / \mathrm{cm}^{2}\right)$. In the reduction process, the lowest current density of $\mathrm{Pt}(\mathrm{E}) / \mathrm{NiO}$ $\left(-5.2 \mathrm{~mA} / \mathrm{cm}^{2}\right)$ also exceeds that of $\mathrm{Pt}(\mathrm{E})\left(-3.9 \mathrm{~mA} / \mathrm{cm}^{2}\right)$. This result is attributed to the fact that a larger active surface area due to a deposited $\mathrm{NiO}$ film corresponds to a more energetic electrocatalytic activity. A similar tendency was also observed by Kim et al. [45] and Yoon et al. [46].

3.3. Photoelectrochemical Behaviour. The J-V characteristics of DSSC in all tests are shown in Figure 7, and Table 1 presents the open-circuit photovoltage $\left(V_{\text {oc }}\right)$, the shortcircuit photocurrent per unit area $\left(J_{\mathrm{sc}}\right)$, the fill factor $(\mathrm{FF})$, and the power conversion efficiency $(\eta)$ of the DSSC in tests D1 to D8. In this study, the $V_{\text {oc }}$ of the DSSC is kept at $0.65 \mathrm{~V}$. The power conversion efficiency of DSSC with $\mathrm{Pt}(\mathrm{E})$ (or $\mathrm{Pt}(\mathrm{E}) / \mathrm{NiO}$ ) exceeds $3 \%$.

At a fixed counter electrode, as the average thickness of $\mathrm{TiO}_{2}$ film increases, the power conversion efficiency increases. For example, for the $\mathrm{Pt}(\mathrm{E})$ counter electrode, the power conversion efficiency increases from $3.00 \%$ to $3.16 \%$ as the average thickness of the $\mathrm{TiO}_{2}$ film increases from $12.0 \mu \mathrm{m}$ (in test D1) to $19.0 \mu \mathrm{m}$ (in test D2). The $J-V$ curve of DSSC with a thicker $\mathrm{TiO}_{2}$ film is above that of DSSC with a thinner $\mathrm{TiO}_{2}$ film (Figure 7). This result is due to the following: (1) a $\mathrm{TiO}_{2}$ film with a larger average thickness contains more $\mathrm{TiO}_{2}(\mathrm{P}-25)$ particles, which may absorb more ultraviolet light; (2) the working electrode with a thicker $\mathrm{TiO}_{2}$ film corresponds to a higher adsorptive capability of the dye because more tiny cavities are created in this film on a FTO-glass substrate so that the larger number of electrons may be excited as the DSSC is exposed to the light.

Although the average thickness of the $\mathrm{TiO}_{2}$ film in test $\mathrm{D} 1(12.0 \mu \mathrm{m})$ is very close to that in test $\mathrm{D} 3(11.0 \mu \mathrm{m})$, the power conversion efficiency of DSSC with a $\mathrm{Pt}(\mathrm{E})$ counter electrode in test D1 $(3.00 \%)$ substantially exceeds that of DSSC with a $\mathrm{Pt}(\mathrm{S})$ counter electrode in test D3 $(2.33 \%)$. This result may be due to the following:. (1) the $\mathrm{Pt}(\mathrm{S})$ counter electrode sheet resistance $(9.73 \Omega / s q)$ significantly exceeds the $\mathrm{Pt}(\mathrm{E})$ counter electrode sheet resistance (5.57 $\Omega / \mathrm{sq}) ;(2)$ at a fixed wavelength, the $\mathrm{Pt}(\mathrm{E})$ counter electrode reflectance remarkably exceeds the $\mathrm{Pt}(\mathrm{S})$ counter electrode reflectance. Fang et al. showed that in order for a DSSC to have better power conversion efficiency, a counter electrode should have the following characteristics: (1) good conductivity for transferring electrons, (2) excellent catalytic activity for $\mathrm{I}^{-} / \mathrm{I}_{3}^{-}$redox, and (3) light-reflecting ability to improve lightharvesting efficiency [50].

Most interestingly, the presence of a NiO film remarkably promotes the power conversion efficiency of DSSC. For example, the power conversion efficiencies of DSSC in tests D2 (with a $\mathrm{Pt}(\mathrm{E})$ counter electrode) and D6 (with a $\mathrm{Pt}(\mathrm{E}) / \mathrm{NiO}$ counter electrode) are $3.16 \%$ and $4.28 \%$, respectively. Furthermore, the power conversion efficiencies of DSSC in tests D4 (with a $\mathrm{Pt}(\mathrm{S})$ counter electrode) and D8 (with a $\mathrm{Pt}(\mathrm{S}) / \mathrm{NiO}$ counter electrode) are $2.34 \%$ and $2.92 \%$, respectively. These results are due to the following: (1) the 


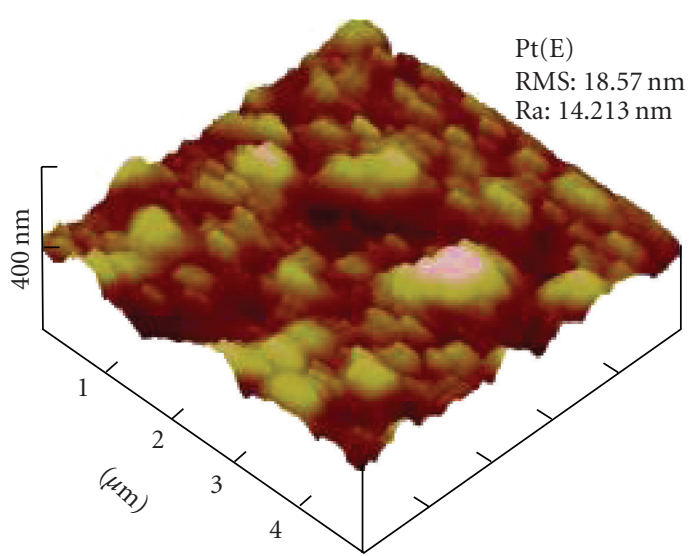

(a)

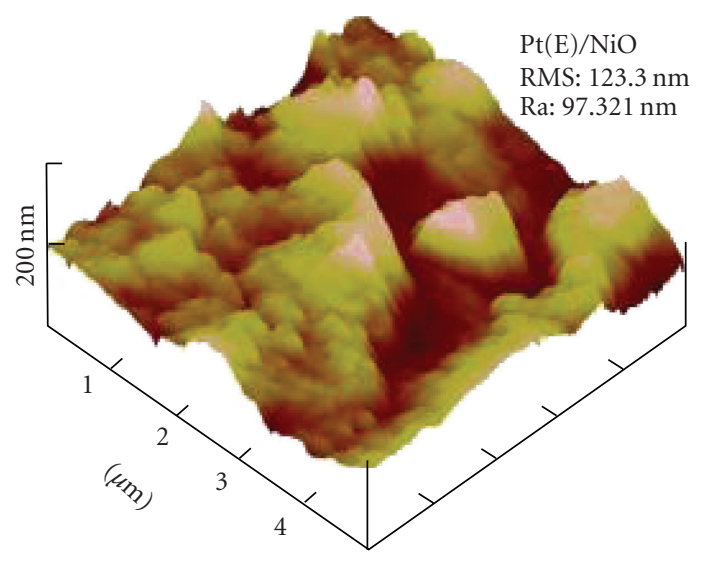

(c)

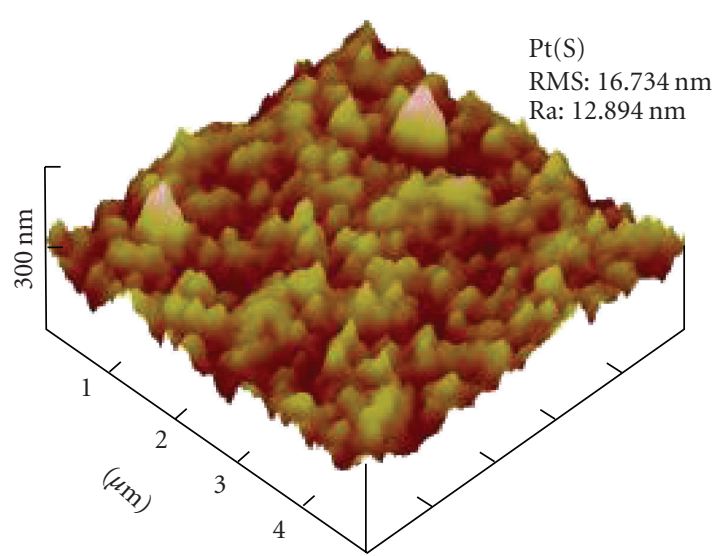

(b)

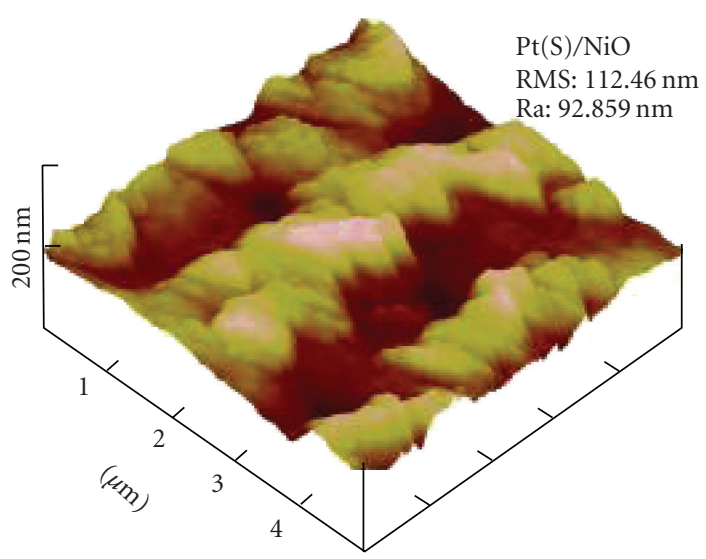

(d)

Figure 5: The 3-D micro-structure of counter electrodes. (a) $\mathrm{Pt}(\mathrm{E})$, (b) $\mathrm{Pt}(\mathrm{S}),(\mathrm{c}) \mathrm{Pt}(\mathrm{E}) / \mathrm{NiO}$, and (d) $\mathrm{Pt}(\mathrm{S}) / \mathrm{NiO}$.

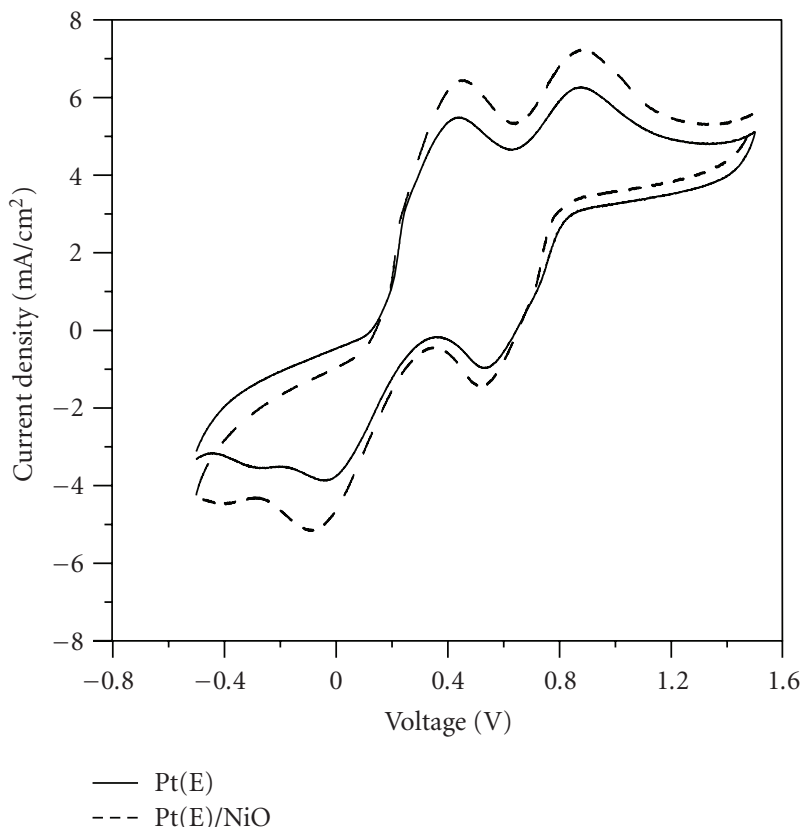

(a)

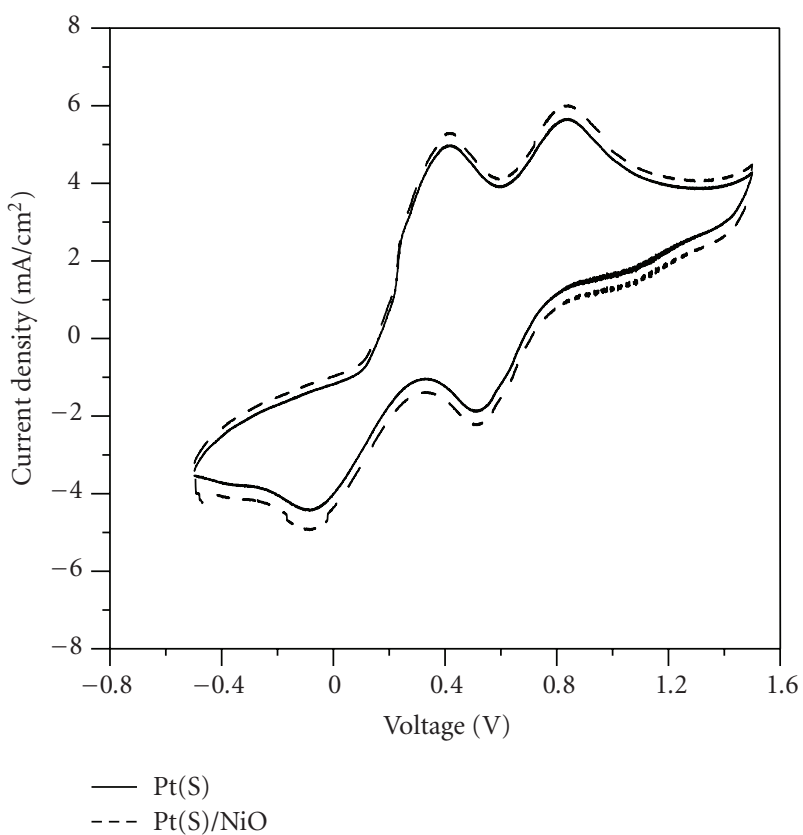

(b)

Figure 6: Cyclic voltammograms (CVs) of counter electrodes of $\mathrm{Pt}(\mathrm{E}), \mathrm{Pt}(\mathrm{S}), \mathrm{Pt}(\mathrm{E}) / \mathrm{NiO}$, and $\mathrm{Pt}(\mathrm{S}) / \mathrm{NiO}$. 


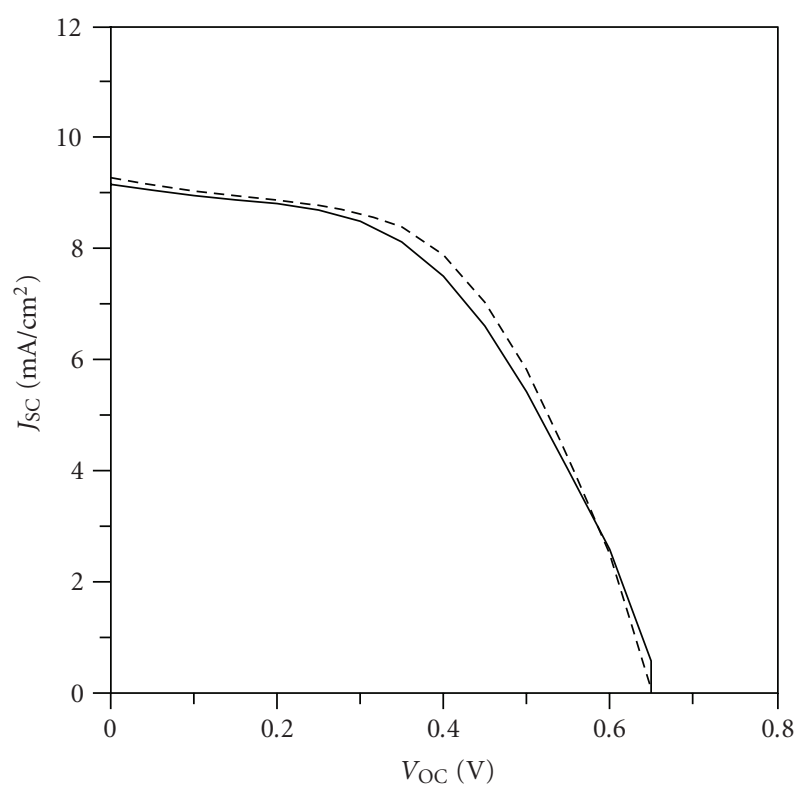

- D1

$---\mathrm{D} 2$

(a)

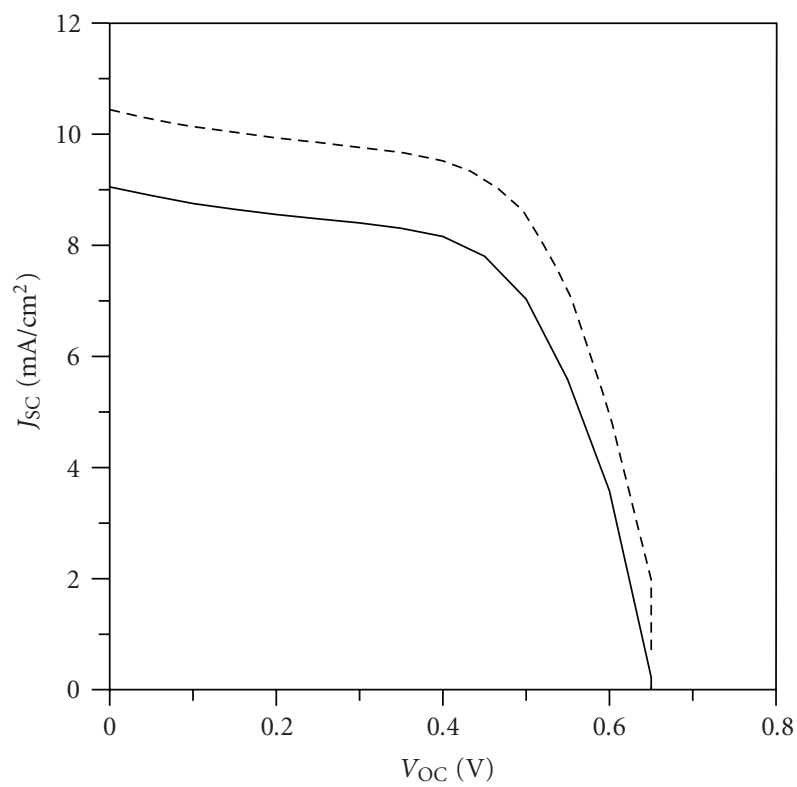

- D5

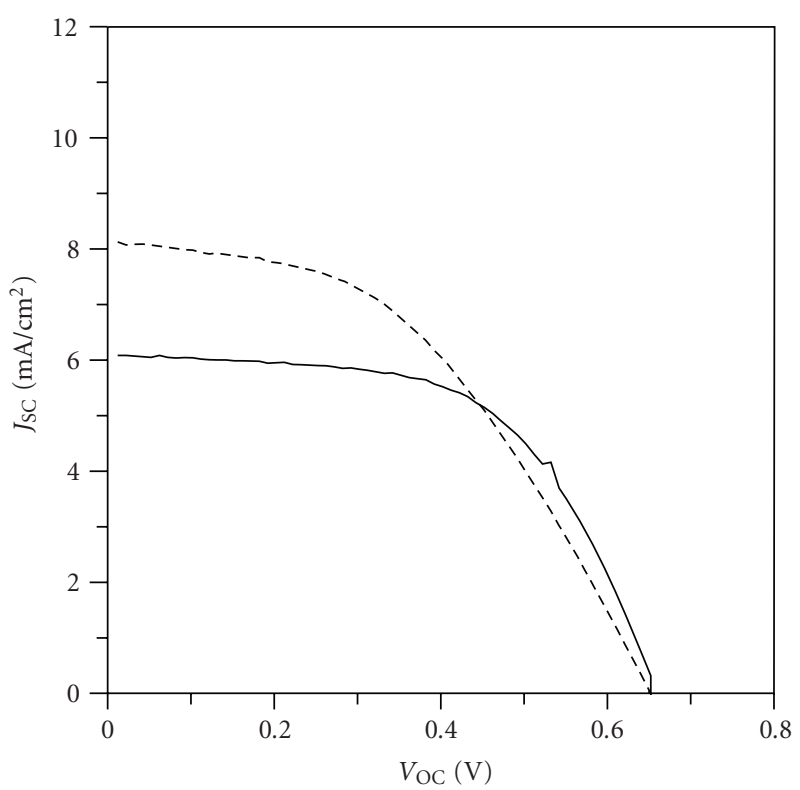

- D3

$---\mathrm{D} 4$

(b)

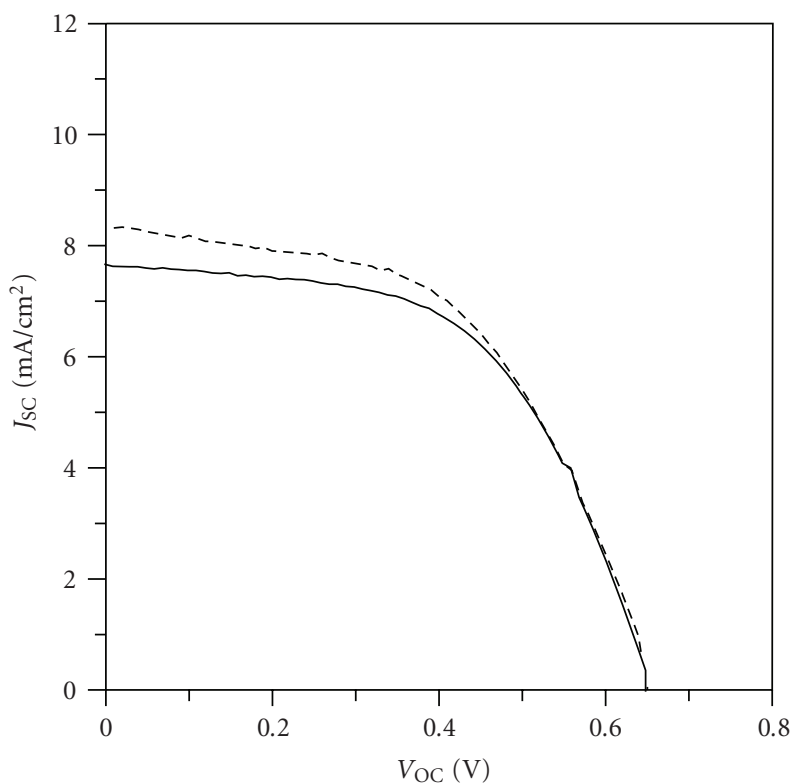

- D7

(c)

(d)

Figure 7: $J-V$ characteristics in tests D1 to D8.

$\mathrm{NiO}$ film deposited on top of $\mathrm{Pt}(\mathrm{E})$ ( or $\mathrm{Pt}(\mathrm{S})$ ) substantially enhances the surface roughness average $(\mathrm{Ra})$ of the counter electrode (Table 1); (2) the increased roughness improves the light scattering as well as the electroactive area of a counter electrode. Kim et al. [45] showed that the overall conversion efficiency of DSSC increased to $3.62 \%$ and $4.21 \%$ through the use of $\mathrm{Pt} / \mathrm{NiO}$ and $\mathrm{Pt} / \mathrm{TiO}_{2}$ bi-phase counter electrodes, respectively.

\section{Conclusion}

The effect of different kinds of counter electrodes on the power conversion efficiency of a DSSC was investigated. The power conversion efficiency of the DSSC with a $\mathrm{Pt}(\mathrm{E})$ counter electrode exceeds that of the DSSC with a $\mathrm{Pt}(\mathrm{S})$ counter electrode because the $\mathrm{Pt}(\mathrm{E})$ counter electrode has better reflectance. Furthermore, the power conversion efficiency of 
the DSSC with a $\mathrm{Pt}(\mathrm{E}) / \mathrm{NiO}$ counter electrode exceeds that of the DSSC with a $\mathrm{Pt}(\mathrm{E})$ counter electrode because the $\mathrm{Pt}(\mathrm{E}) / \mathrm{NiO}$ counter electrode has better electrocatalytic activity. Most importantly, this study supports the application of a NiO film deposited on the Pt-FTO substrate using a simple spin coating method to improve the performance of a DSSC. However, the optimal process for fabricating a DSSC with a $\mathrm{NiO}$ film on the counter electrode, which can promote the electrocatalytic activity of the counter electrode, must be implemented to yield a DSSC with a satisfactory power conversion efficiency.

Concerning the possible application of this nontransparent cathode that the $\mathrm{NiO}$ is deposited on top of the Pt film, it may decline the transparency of photovoltaic windows. However, besides photovoltaic windows, the other real applications of DSSC, such as DSSC lampshade, flower-shaped DSSC, and leaf-shaped DSSC, whose transparency may not be seriously considered, have received substantial attention, too. We believe that this counter electrode may facilitate the performance of aforementioned devices of DSSC.

\section{Acknowledgments}

The authors would like to thank the National Science Council, Taiwan for financially supporting this research under Contract nos. NSC 97-2221-E-020-035 and NSC 972918-I-020-001. The authors would also like to thank the National Pingtung University of Science and Technology, Taiwan for their financial support to establish the Research Center of Solar Photo-Electricity Applications.

\section{References}

[1] B. O’Regan and M. Grätzel, "A low-cost, high-efficiency solar cell based on dye-sensitized colloidal $\mathrm{TiO}_{2}$ films," Nature, vol. 353, no. 6346, pp. 737-740, 1991.

[2] N. S. Lewis, "Toward cost-effective solar energy use," Science, vol. 315, no. 5813, pp. 798-801, 2007.

[3] S. Kim, D. Kim, H. Choi et al., "Enhanced photovoltaic performance and long-term stability of quasi-solid-state dyesensitized solar cells via molecular engineering," Chemical Communications, no. 40, pp. 4951-4953, 2008.

[4] M. Wei, Y. Konishi, H. Zhou, H. Sugihara, and H. Arakawa, "Utilization of titanate nanotubes as an electrode material in dye-sensitized solar cells," Journal of the Electrochemical Society, vol. 153, no. 6, pp. A1232-A1236, 2006.

[5] G.-S. Kim, H.-K. Seo, V. P. Godble, Y.-S. Kim, O.-B. Yang, and H.-S. Shin, "Electrophoretic deposition of titanate nanotubes from commercial titania nanoparticles: application to dyesensitized solar cells," Electrochemistry Communications, vol. 8, no. 6, pp. 961-966, 2006.

[6] S.-J. Roh, R. S. Mane, S.-K. Min, W.-J. Lee, C. D. Lokhande, and S.-H. Han, "Achievement of $4.51 \%$ conversion efficiency using $\mathrm{ZnO}$ recombination barrier layer in $\mathrm{TiO}_{2}$ based dyesensitized solar cells," Applied Physics Letters, vol. 89, no. 25, Article ID 253512, 2006.

[7] Y. H. Su, W. H. Lai, L. G. Teoh, M. H. Hon, and J. L. Huang, "Layer-by-layer Au nanoparticles as a Schottky barrier in a water-based dye-sensitized solar cell," Applied Physics A, vol. 88, no. 1, pp. 173-178, 2007.
[8] J. Bandara and J. P. Yasomanee, "P-type oxide semiconductors as hole collectors in dye-sensitized solid-state solar cells," Semiconductor Science and Technology, vol. 22, no. 2, pp. 2024, 2007.

[9] S. Ito, T. N. Murakami, P. Comte et al., "Fabrication of thin film dye sensitized solar cells with solar to electric power conversion efficiency over 10\%," Thin Solid Films, vol. 516, no. 14, pp. 4613-4619, 2008.

[10] S. Sumikura, S. Mori, S. Shimizu, H. Usami, and E. Suzuki, "Syntheses of $\mathrm{NiO}$ nanoporous films using nonionic triblock co-polymer templates and their application to photo-cathodes of p-type dye-sensitized solar cells," Journal of Photochemistry and Photobiology A, vol. 199, no. 1, pp. 1-7, 2008.

[11] S. Sumikura, S. Mori, S. Shimizu, H. Usami, and E. Suzuki, "Photoelectrochemical characteristics of cells with dyed and undyed nanoporous p-type semiconductor $\mathrm{CuO}$ electrodes," Journal of Photochemistry and Photobiology A, vol. 194, no. 23, pp. 143-147, 2008.

[12] C.-S. Chou, R.-Y. Yang, M.-H. Weng, and C.-H. Yeh, "Study of the applicability of $\mathrm{TiO}_{2}$ /dye composite particles for a dyesensitized solar cell," Advanced Powder Technology, vol. 19, no. 6, pp. 541-558, 2008.

[13] C.-S. Chou, R.-Y. Yang, M.-H. Weng, and C.-H. Yeh, "Preparation of $\mathrm{TiO}_{2}$ /dye composite particles and their applications in dye-sensitized solar cell," Powder Technology, vol. 187, no. 2, pp. 181-189, 2008.

[14] K.-M. Lee, C.-W. Hu, H.-W. Chen, and K.-C. Ho, "Incorporating carbon nanotube in a low-temperature fabrication process for dye-sensitized $\mathrm{TiO}_{2}$ solar cells," Solar Energy Materials and Solar Cells, vol. 92, no. 12, pp. 1628-1633, 2008.

[15] B. Yoo, K. Kim, S. H. Lee, W. M. Kim, and N.-G. Park, "ITO/ATO/TiO 2 triple-layered transparent conducting substrates for dye-sensitized solar cells," Solar Energy Materials and Solar Cells, vol. 92, no. 8, pp. 873-877, 2008.

[16] B. N. Pawar, G. Cai, D. Ham et al., "Preparation of transparent and conducting boron-doped $\mathrm{ZnO}$ electrode for its application in dye-sensitized solar cells," Solar Energy Materials and Solar Cells, vol. 93, no. 4, pp. 524-527, 2009.

[17] K.-M. Lee, V. Suryanarayanan, and K.-C. Ho, "Influences of different $\mathrm{TiO}_{2}$ morphologies and solvents on the photovoltaic performance of dye-sensitized solar cells," Journal of Power Sources, vol. 188, no. 2, pp. 635-641, 2009.

[18] W. J. Lee, E. Ramasamy, and D. Y. Lee, "Effect of electrode geometry on the photovoltaic performance of dye-sensitized solar cells," Solar Energy Materials and Solar Cells, vol. 93, no. 8, pp. 1448-1451, 2009.

[19] U. O. Krašovec, M. Berginc, M. Hočevar, and M. Topič, "Unique $\mathrm{TiO}_{2}$ paste for high efficiency dye-sensitized solar cells," Solar Energy Materials and Solar Cells, vol. 93, no. 3, pp. 379-381, 2009.

[20] T. Sawatsuk, A. Chindaduang, C. Sae-kung, S. Pratontep, and G. Tumcharern, "Dye-sensitized solar cells based on $\mathrm{TiO}_{2}$ MWCNTs composite electrodes: performance improvement and their mechanisms," Diamond and Related Materials, vol. 18, no. 2-3, pp. 524-527, 2009.

[21] H. Wang, Y. Liu, H. Xu et al., "An investigation on the novel structure of dye-sensitized solar cell with integrated photoanode," Renewable Energy, vol. 34, no. 6, pp. 1635-1638, 2009.

[22] C.-S. Chou, R.-Y. Yang, C.-K. Yeh, and Y.-J. Lin, "Preparation of $\mathrm{TiO}_{2}$ /Nano-metal composite particles and their applications in dye-sensitized solar cells," Powder Technology, vol. 194, no. 1-2, pp. 95-105, 2009. 
[23] S. Hwang, J. H. Lee, C. Park et al., "A highly efficient organic sensitizer for dye-sensitized solar cells," Chemical Communications, no. 46, pp. 4887-4889, 2007.

[24] J.-G. Chen, C.-Y. Chen, S.-J. Wu, J.-Y. Li, C.-G. Wu, and K.-C. Ho, "On the photophysical and electrochemical studies of dyesensitized solar cells with the new dye CYC-B1," Solar Energy Materials and Solar Cells, vol. 92, no. 12, pp. 1723-1727, 2008.

[25] S. Ito, H. Miura, S. Uchida et al., "High-conversion-efficiency organic dye-sensitized solar cells with a novel indoline dye," Chemical Communications, no. 41, pp. 5194-5196, 2008.

[26] M. Xu, R. Li, N. Pootrakulchote et al., "Energy-level and molecular engineering of organic D- $\pi$-A sensitizers in dyesensitized solar cells," Journal of Physical Chemistry C, vol. 112, no. 49, pp. 19770-19776, 2008.

[27] C.-H. Yang, H.-L. Chen, Y.-Y. Chuang et al., "Characteristics of triphenylamine-based dyes with multiple acceptors in application of dye-sensitized solar cells," Journal of Power Sources, vol. 188, no. 2, pp. 627-634, 2009.

[28] J. Pei, S. Peng, J. Shi et al., "Triphenylamine-based organic dye containing the diphenylvinyl and rhodanine-3-acetic acid moieties for efficient dye-sensitized solar cells," Journal of Power Sources, vol. 187, no. 2, pp. 620-626, 2009.

[29] V. Kandavelu, H.-S. Huang, J.-L. Jian, T. C.-K. Yang, K.L. Wang, and S.-T. Huang, "Novel iminocoumarin dyes as photosensitizers for dye-sensitized solar cell," Solar Energy, vol. 83 , no. 4, pp. 574-581, 2009.

[30] T. Kato, T. Kado, S. Tanaka, A. Okazaki, and S. Hayase, "Quasi-solid dye-sensitized solar cells containing nanoparticles modified with ionic liquid-type molecules," Journal of the Electrochemical Society, vol. 153, no. 3, pp. A626-A630, 2006.

[31] T. C. Wei, C. C. Wan, and Y. Y. Wang, "Preparation and characterization of a micro-porous polymer electrolyte with cross-linking network structure for dye-sensitized solar cell," Solar Energy Materials and Solar Cells, vol. 91, no. 20, pp. 1892-1897, 2007.

[32] S. Ganesan, B. Muthuraaman, V. Mathew, J. Madhavan, P. Maruthamuthu, and S. Austin Suthanthiraraj, "Performance of a new polymer electrolyte incorporated with diphenylamine in nanocrystalline dye-sensitized solar cell," Solar Energy Materials and Solar Cells, vol. 92, no. 12, pp. 1718-1722, 2008.

[33] Y. Wang, Y. Sun, B. Song, and J. Xi, "Ionic liquid electrolytes based on 1-vinyl-3-alkylimidazolium iodides for dyesensitized solar cells," Solar Energy Materials and Solar Cells, vol. 92, no. 6, pp. 660-666, 2008.

[34] D. Shi, N. Pootrakulchote, R. Li et al., "New efficiency records for stable dye-sensitized solar cells with low-volatility and ionic liquid electrolytes," Journal of Physical Chemistry C, vol. 112, no. 44, pp. 17046-17050, 2008.

[35] K.-M. Lee, P.-Y. Chen, C.-P. Lee, and K.-C. Ho, "Binary roomtemperature ionic liquids based electrolytes solidified with $\mathrm{SiO}_{2}$ nanoparticles for dye-sensitized solar cells," Journal of Power Sources, vol. 190, no. 2, pp. 573-577, 2009.

[36] T. Kato and S. Hayase, "Quasi-solid dye sensitized solar cell with straight ion paths. Proposal of hybrid electrolytes for ionic liquid-type electrolytes," Journal of the Electrochemical Society, vol. 154, no. 1, pp. B117-B121, 2007.

[37] A. Kay and M. Grätzel, "Low cost photovoltaic modules based on dye sensitized nanocrystalline titanium dioxide and carbon powder," Solar Energy Materials and Solar Cells, vol. 44, no. 1, pp. 99-117, 1996.

[38] T. N. Murakami, S. Ito, Q. Wang et al., "Highly efficient dye-sensitized solar cells based on carbon black counter electrodes," Journal of the Electrochemical Society, vol. 153, no. 12, pp. A2255-A2261, 2006.

[39] Z. Huang, X. Liu, K. Li et al., "Application of carbon materials as counter electrodes of dye-sensitized solar cells," Electrochemistry Communications, vol. 9, no. 4, pp. 596-598, 2007.

[40] C.-S. Chou, R.-Y. Yang, M.-H. Weng, and C.-I. Huang, "The applicability of SWCNT on the counter electrode for the dyesensitized solar cell," Advanced Powder Technology, vol. 20, no. 4, pp. 310-317, 2009.

[41] E. Ramasamy, W. J. Lee, D. Y. Lee, and J. S. Song, "Spray coated multi-wall carbon nanotube counter electrode for tri-iodide $\left(\mathrm{I}_{3}^{-}\right)$reduction in dye-sensitized solar cells," Electrochemistry Communications, vol. 10, no. 7, pp. 1087-1089, 2008.

[42] E. Ramasamy, W. J. Lee, D. Y. Lee, and J. S. Song, "Nanocarbon counterelectrode for dye sensitized solar cells," Applied Physics Letters, vol. 90, no. 17, Article ID 173103, 2007.

[43] W. J. Lee, E. Ramasamy, D. Y. Lee, and J. S. Song, "Grid type dye-sensitized solar cell module with carbon counter electrode," Journal of Photochemistry and Photobiology A, vol. 194, no. 1, pp. 27-30, 2008.

[44] S.-S. Kim, K.-W. Park, J.-H. Yum, and Y.-E. Sung, "Pt-NiO nanophase electrodes for dye-sensitized solar cells," Solar Energy Materials and Solar Cells, vol. 90, no. 3, pp. 283-290, 2006.

[45] S.-S. Kim, K.-W. Park, J.-H. Yum, and Y.-E. Sung, "Dyesensitized solar cells with $\mathrm{Pt}-\mathrm{NiO}$ and $\mathrm{Pt}-\mathrm{TiO}_{2}$ biphase counter electrodes," Journal of Photochemistry and Photobiology A, vol. 189, no. 2-3, pp. 301-306, 2007.

[46] C. H. Yoon, R. Vittal, J. Lee, W.-S. Chae, and K.-J. Kim, "Enhanced performance of a dye-sensitized solar cell with an electrodeposited-platinum counter electrode," Electrochimica Acta, vol. 53, no. 6, pp. 2890-2896, 2008.

[47] H. Fornander, J. Birch, P. Sandström, and J.-E. Sundgren, "Structure evolution of epitaxial Pd grown on $\mathrm{MgO}(001)$ : a comparison between sputtering and electron-beam evaporation," Thin Solid Films, vol. 349, no. 1, pp. 4-9, 1999.

[48] Z. Song and C. Lin, "Microstructure and electrical properties of $\mathrm{PbZr}_{0.48} \mathrm{Ti}_{0.52} \mathrm{O}_{3}$ ferroelectric films on different Pt bottom electrodes," Applied Surface Science, vol. 158, no. 1, pp. 21-27, 2000 .

[49] K. Imoto, K. Takahashi, T. Yamaguchi, T. Komura, J.-I. Nakamura, and K. Murata, "High-performance carbon counter electrode for dye-sensitized solar cells," Solar Energy Materials and Solar Cells, vol. 79, no. 4, pp. 459-469, 2003.

[50] X. Fang, T. Ma, G. Guan, M. Akiyama, T. Kida, and E. Abe, "Effect of the thickness of the Pt film coated on a counter electrode on the performance of a dye-sensitized solar cell," Journal of Electroanalytical Chemistry, vol. 570, no. 2, pp. 257263, 2004. 


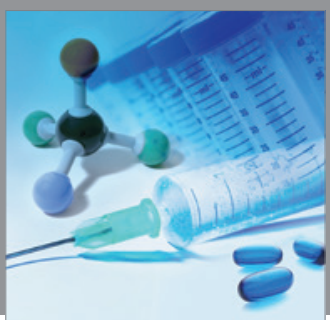

International Journal of

Medicinal Chemistry

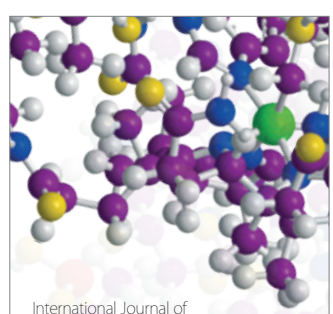

Carbohydrate Chemistry

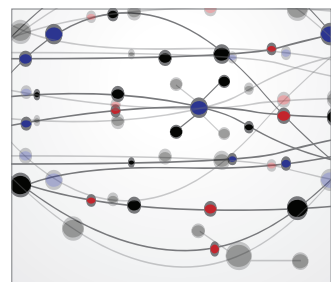

The Scientific World Journal
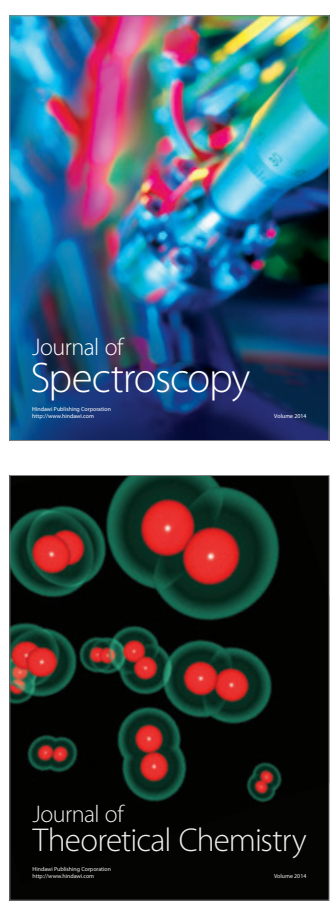
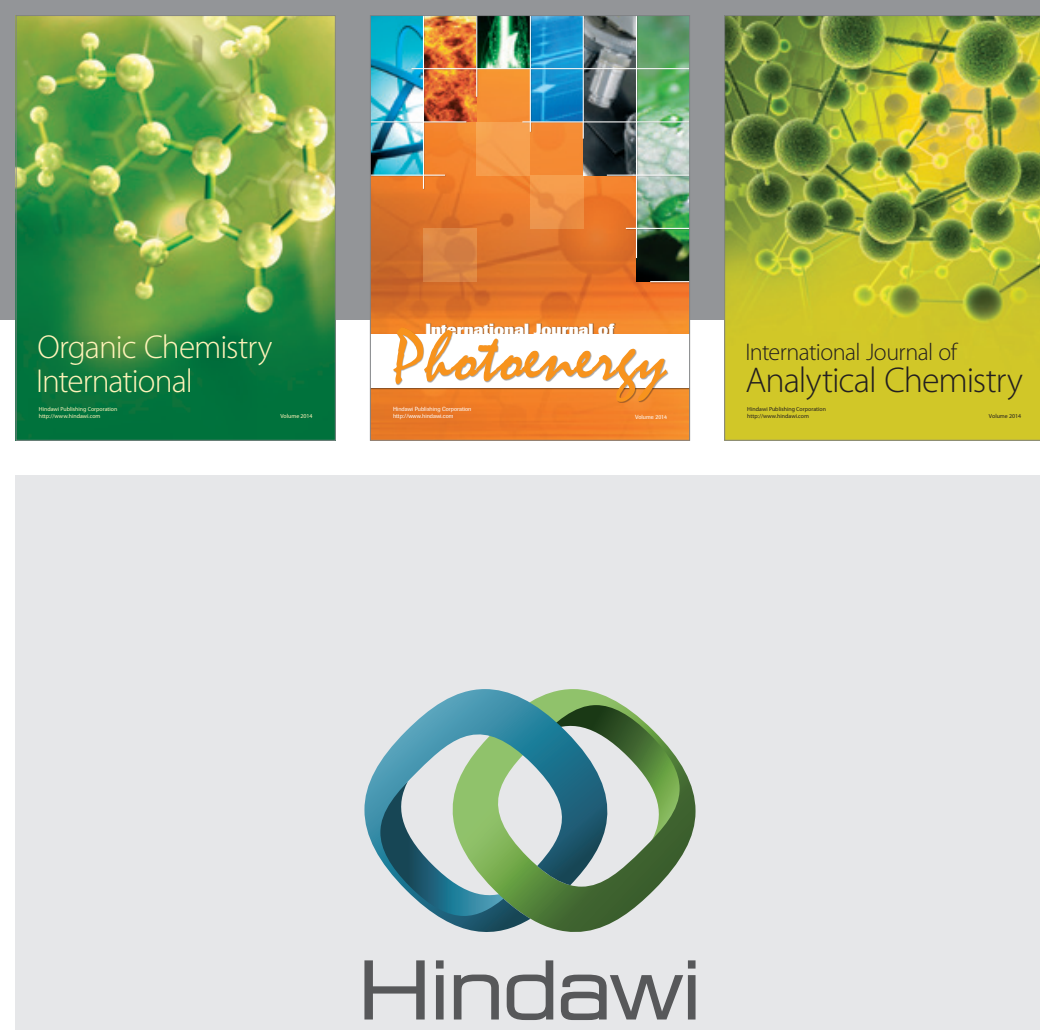

Submit your manuscripts at

http://www.hindawi.com
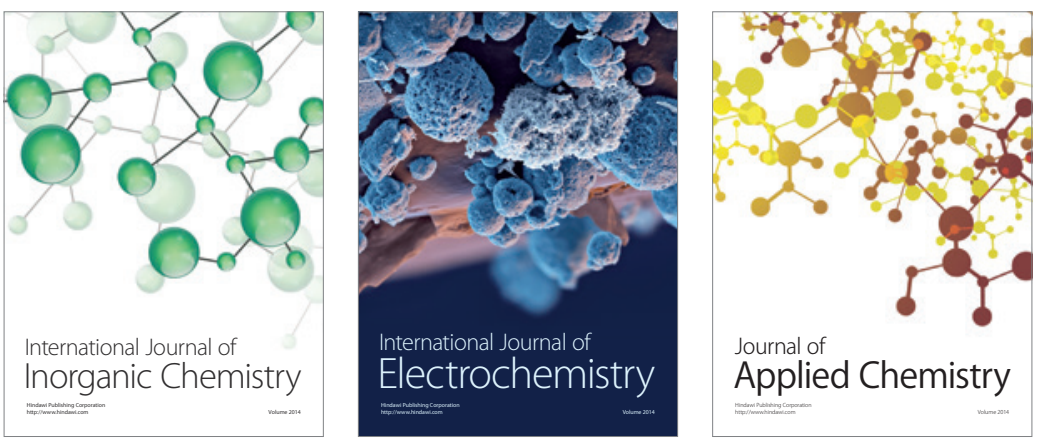

Journal of

Applied Chemistry
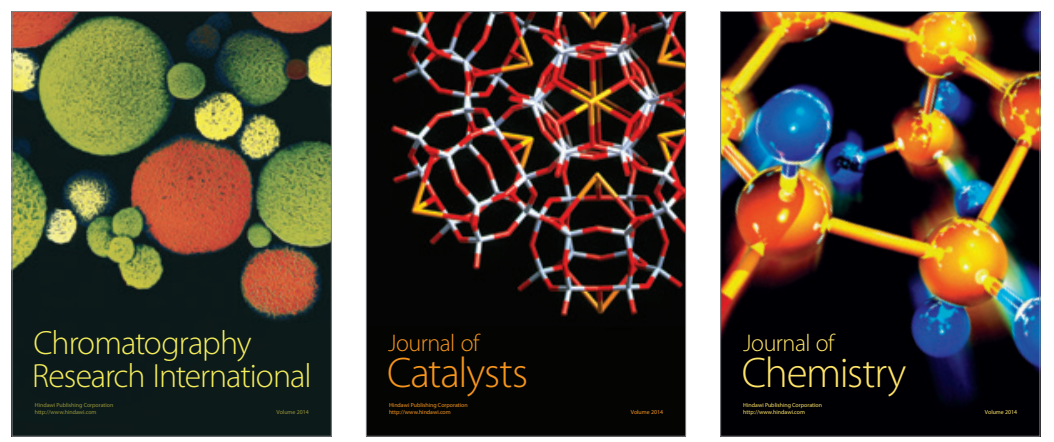
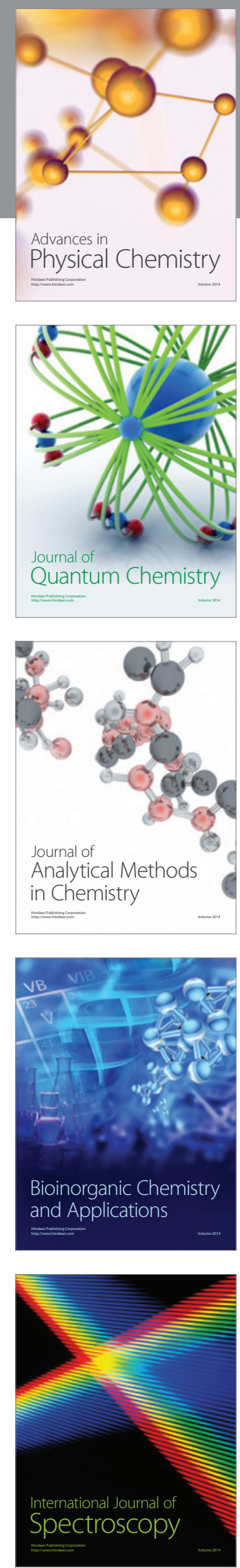